\title{
The ancient roots of calcium signalling evolutionary tree
}

\author{
Helmut Plattner ${ }^{\mathrm{a}, *}$, Alexei Verkhratsky ${ }^{\mathrm{b}, \mathrm{c}, \mathrm{d}}$ \\ a Faculty of Biology, University of Konstanz, 78457 Konstanz, Germany \\ ${ }^{\mathrm{b}}$ Faculty of Biological Sciences, University of Manchester, Manchester M13 9PT, UK \\ ' Achucarro Centre for Neuroscience, IKERBASQUE, Basque Foundation for Science, 48011 Bilbao, Spain \\ ' University of Nizhny Novgorod, Nizhny Novgorod 603022, Russia
}

\begin{abstract}
A B S T R A C T
Molecular cascades of calcium homeostasis and signalling $\left(\mathrm{Ca}^{2+}\right.$ pumps, channels, cation exchangers, and $\mathrm{Ca}^{2+}$-binding proteins) emerged in prokaryotes and further developed at the unicellular stage of eukaryote evolution. With progressive evolution, mechanisms of signalling became diversified reflecting multiplication and specialisation of $\mathrm{Ca}^{2+}$-regulated cellular activities. Recent genomic analysis of organisms from different systematic positions, combined with proteomic and functional probing invigorated expansion in our understanding of the evolution of $\mathrm{Ca}^{2+}$ signalling. Particularly impressive is the consistent role of $\mathrm{Ca}^{2+}$-ATPases/pumps, calmodulin and calcineurin from very early stages of eukaryotic evolution, although with interspecies differences. Deviations in $\mathrm{Ca}^{2+}$ handling and signalling are observed between vertebrates and flowering plants as well as between protists at the basis of the two systematic categories, Unikonta (for example choanoflagellates) and Bikonta (for example ciliates). Only the B-subunit of calcineurin, for instance, is maintained to regulate highly diversified protein kinases for stress defence in flowering plants, whereas the complete dimeric protein, in vertebrates up to humans, regulates gene transcription, immune-defence and plasticity of the brain. Calmodulin is similarly maintained throughout evolution, but in plants a calmoldulin-like domain is integrated into protein kinase molecules. The eukaryotic cell has inherited and invented many mechanisms to exploit the advantages of signalling by $\mathrm{Ca}^{2+}$, and there is considerable overall similarity in basic processes of $\mathrm{Ca}^{2+}$ regulation and signalling during evolution, although some details may vary.
\end{abstract}

\section{Bacterial inheritance: $\mathrm{Ca}^{2+}$ regulation and primaeval $\mathrm{Ca}^{2+}$ signalling}

Early life may have emerged in the ocean or in local parts of it under alkaline conditions that favoured relatively low (in a $100 \mathrm{~s}$ nM range) $\mathrm{Ca}^{2+}$ concentrations ([1,2] this special issue). At this early stage $\mathrm{Ca}^{2+}$ permeation into ancestral cells, $\mathrm{Ca}^{2+}$ handling and $\mathrm{Ca}^{2+}$ influence on energetic (and in particular the requirement of low free $\mathrm{Ca}^{2+}$ for ATP metabolism [3]) made $\mathrm{Ca}^{2+}$ ions critical for life and for signalling processes.

Bacteria maintain $\mathrm{Ca}^{2+}$ homeostasis [4,5] although resting levels of free cytosolic $\mathrm{Ca}^{2+}$ concentration $\left(\left[\mathrm{Ca}^{2+}\right]_{i}\right)$ are somewhat higher than in eukaryotes [6] and although specific mechanisms employed by different bacterial species are yet to be characterised in detail.

\footnotetext{
* Corresponding author at: Department of Biology, University of Konstanz, Room M1132, P. O. Box M625, 78457 Konstanz, Germany. Tel.: +49 753188 2228; fax: +497531882168 .

E-mail address: helmut.plattner@uni-konstanz.de (H. Plattner).
}

Some bacteria express primary and secondary active transporters including P-type $\mathrm{Ca}^{2+}$-transport ATPases of which several resemble the Sarcoplasmic and Endoplasmic Reticulum $\underline{\mathrm{Ca}^{2+}}$-ATTPase (SERCA) of eukaryotes $[7,8]$. These pumps, together with mechanosensitive channels [9], $\mathrm{Ca}^{2+}$-activated channels [10], cation exchangers, such as $\mathrm{Ca}^{2+} / \mathrm{H}^{+}$and $\mathrm{Ca}^{2+} / \mathrm{Na}^{+}$exchangers, an array of $\mathrm{Ca}^{2+}$-binding proteins (CaBP), and a battery of $\mathrm{Ca}^{2+}$-activated enzymes, which all are present in bacteria ([11] this special issue) formed the primordial $\mathrm{Ca}^{2+}$ homeostatic and $\mathrm{Ca}^{2+}$ signalling system. In bacteria which live today, changes in $\left[\mathrm{Ca}^{2+}\right]_{i}$, regulate numerous functions such as, for example, chemotaxis [6,12]. Calmodulin-like proteins are found in the genome of certain Gram-positive bacteria [13-15], in addition to other CaBPs [16]. However, fast $\mathrm{Ca}^{2+}$ sensors with $\mathrm{C} 2$ domains (such as for example synaptotagmins [17]) have not been reported.

Considering the frequent occurrence of gene transfer between ancestral organisms, the early period of evolution of molecular cascades responsible for control over cellular $\mathrm{Ca}^{2+}$ remains rather vague and speculative. Even genuine $\mathrm{Ca}^{2+}$ signalling in bacteria has been debated [10]. Apart from these restrictions it appears that 
bacteria prophesied several important mechanisms that have been advanced and refined throughout the evolutionary ladder.

\section{From bacteria to the eukaryote cell: requirement of $\mathrm{Ca}^{2+}$ for trafficking}

There is considerable uncertainty about the origin of the eukaryotic cell from archaebacteria or eubacteria [18], with different scenarios being proposed $[19,20]$. Even the age of eukaryotes is disputed; the classical (and prevailing) view of their emergence (as witnessed by fossils) $\sim 2$ billion years ago [21-24], is not universally acknowledged with the data on the presence of eukaryotic markers in much older ( $\sim 3$ to $\sim 3.5$ billion years) fossils $[25,26]$. Based on the analysis of eukaryotic signature proteins, the emergence of a "chronocyte", the intermediate distinct from Archaea and eubacteria has been contemplated [27]. The textbook view highlights an archaebacterial ancestor whose genome has been sequestered by another cell through invagination of the cell membrane. Integration of an archaebacterium into an eubacterium is another hypothetic scenario. The $\mathrm{Ca}^{2+}$ regulating and $\mathrm{Ca}^{2+}$ regulated proteins outlined above are essentially known from eubacteria, whereas important proteins of the nucleus have orthologues in some archaebacteria [28].

By infolding of the cell membrane with ribosomes attached, the Endoplasmic Reticulum (ER) could have formed, followed by controlled blebbing and fusion of vesicular compartments, also a $\mathrm{Ca}^{2+}$-dependent process, wherever it has been accessible to analysis. This must have been prerequisite to any further differentiation and trafficking. This capability, together with a cytoskeleton, has been ascribed to the chronocyte [27]. In contrast, a LAECA-(latest archaeal-eukaryote common ancestor) type organisms, endowed with high internal complexity, has been postulated to precede genuine eukaryotes [29]. Endocytosis and intracellular digestion are thought to have become important for further complexity of the LAECA-type ancestor, and the early eukaryotic cell [30,31]. The acquisition of endomembranes and intracellular compartments that could emerge in some prokaryotes was certainly associated with the transition from prokaryotes to eukaryotes and prompted new developments in $\mathrm{Ca}^{2+}$ signalling.

Regulation of intracellular trafficking become the special function of $\mathrm{Ca}^{2+}$, which generally assumes a key role in membranemembrane interactions, and hence complex $\left[\mathrm{Ca}^{2+}\right]_{i}$ dynamics, regulated in space and time, provided a canvass for ubiquitous and versatile $\mathrm{Ca}^{2+}$ signalling. $\mathrm{Ca}^{2+}$ has outstanding properties that make it an almost ideal second messenger [32]. Since too high $\left[\mathrm{Ca}^{2+}\right]_{i}$ is toxic, strict regulation and "taming" of $\mathrm{Ca}^{2+}$ movements is required, which have made it a molecule suitable for signalling at a low additional energy costs. The human body contains up to $1.4-2 \mathrm{~kg}$ of $\mathrm{Ca}^{2+}$ (of which $99 \%$ is present in the form of insoluble phosphates accumulated in bones). Concentration of $\mathrm{Ca}^{2+}$ is $\sim 10 \mathrm{mM}$ in the ocean; total $\mathrm{Ca}^{2+}$ concentration reaches $25 \mathrm{mM}$ in plants; in mammalian cells, total $\mathrm{Ca}^{2+}$ concentration in the cytoplasm (free and bound) is in the millimolar range [32], whereas free concentrations of $\left[\mathrm{Ca}^{2+}\right]_{i}$ are, as a rule, below $\sim 0.1$ micromolar in the resting cell [33]. The existence of a continuous concentration gradient aimed at the cytosol allows $\left[\mathrm{Ca}^{2+}\right]_{i}$ to be rapidly and locally increased for signalling at defined sites, which rise is followed by reversible binding to CaBPs. These latter proteins are generally characterised by rapid binding kinetics and widely different affinity (expressed as a binding constant, $K_{\mathrm{D}}$ ). High capacity/low affinity binding makes some CaBPs suitable for $\mathrm{Ca}^{2+}$ binding inside the organelles (universally known as dynamic $\mathrm{Ca}^{2+}$ stores) and for signal inactivation in the cytosol, whereas rapid activation of dynamic processes is a responsibility of low capacity/high affinity binding with a variety of membrane-bound and cytosolic CaBPs. Local regulation of
$\mathrm{Ca}^{2+}$ controls selective and spatially restricted specific processes [33], avoids toxicity and keeps energetic costs for re-establishing homeostasis low. For the latter purpose, some high capacity/low affinity CaBPs are also present in the cytosol [34].

\section{An evolutionary time scale and diversification of $\mathrm{Ca}^{2+}$ signalling}

Ancestral eukaryotes diversified into two main branches, Unikonta (that eventually evolved into vertebrates) and Bikonta (that are at the root of angiosperms, or flowering plants $[35,36]$ ). The founders of these branches are two unicellular groups whose current main representatives date back to $\sim 760-960$ million of years (choanoflagellates [37]) and $\sim 800$ million of years (ciliates [23]). Choanoflagellates are considered as the founding group of metazoa and, therefore, deserve special interest with regard to $\mathrm{Ca}^{2+}$ signalling (Cai et al. [48], this special issue). Myxamoebae (Dictyostelium) are another well analysed unikont; their phylogenetic age is somewhat ambiguous, although they can be younger than the other groups [38]. Mammals are more than 200 million of years old being therefore older than flowering plants that are believed to emerge 130-190 million of years ago [23,39].

Molecules participating in trafficking have greatly diversified during evolution, which could be extrapolated from comparative genomic studies. There are about 20 SNAREs (soluble N-ethyl maleimide sensitive attachment protein receptors) in the Ureukaryote, whereas they are about twice as many in mammals [40]. The number of Rab-type GTPases increased from an estimated 20 in ancestral eukaryote [41] to 163 in human [42]. Insights from cells living today suggests that already in early times $\mathrm{Ca}^{2+}$ must have been "hired" for signalling purposes. Considering rapid diffusion, binding and deactivation of $\mathrm{Ca}^{2+}$, increasingly elaborate intracellular trafficking required a strict localisaton of $\mathrm{Ca}^{2+}$ signals. This in turn requires $\mathrm{Ca}^{2+}$ stores, with high capacity/low affinity CaBPs in their lumen, and mechanisms for $\mathrm{Ca}^{2+}$ uptake and local release $[43,44]$. All these components, including primary and secondary active $\mathrm{Ca}^{2+}$ transport mechanisms and $\underline{\mathrm{Ca}}^{2+}$ release channels (CRC) are abundant in protozoa in one or the other form, as found in Paramecium [45,46], and to some extent in Dictyostelium [47] and in choanoflagellates ([48], this special issue). The first two genera represent the major phylogenetic lines and are frequently used for studies in cell biology, whereas choanoflagellates are currently only analysed by molecular biology, although with important predictions. The increasing importance of $\mathrm{Ca}^{2+}$ during evolution is highlighted by an increase in the number of CaBPs, which rises from $\sim 70$ in bacteria to 3640 in mammals [16,49]. Substantial increase in numbers and diversity of $\mathrm{CaBP}$ in eukaryotes reflects a rising capability of fine tuning $\mathrm{Ca}^{2+}$ signals [50]. A rather different way of diversification of $\mathrm{Ca}^{2+}$ signalling, however, is observed in plants ([51-53] in this special issue).

It is now generally acknowledged that evolutionary improvement of cell energetic is associated with endocytosis and domestication of eubacteria with respiratory activity, that become mitochondria, about 1.5 billion years ago [54]. Considering the high proportion of energy investment in ionic balance in modern eukaryotes, one may assume that acquisition of mitochondrial precursors was an important step in advancement of $\mathrm{Ca}^{2+}$ signalling ([2], this special issue). The uptake of $\mathrm{Ca}^{2+}$ by mitochondria, achieved in modern eukaryotes by an uniporter [55] is swift and it stimulates ATP production by activating dehydrogenases in the mitochondrial matrix [56]. A homologue of $\mathrm{Ca}^{2+}$ uniporter is present already in bacteria [57], and in choanoflagellates ([48], this special issue), while a mitochondrial calcium uniporter (MCU) is conserved from protozoa to human, no MCU homologues, however, were found in various parasitic protozoa $[57,58]$. The essential 
$\underline{M C U}$ regulator, EMRE, is absent in some protozoa analysed, including Dictyostelium and Tetrahymena [58], thus probably indicating lower capability for adjustment of $\mathrm{Ca}^{2+}$ transport. In summary, during evolution, mitochondria are actively engaged regulating and exploiting energetically $\mathrm{Ca}^{2+}$ signals, but with some variability.

Considering the great age of the most ancient forms of eukaryotes we have to concede that cells of modernity are remote descendants, with ample chances for parallel evolution, possibly also including gene transfer, thus disguising images of the distant past. However, the multitude of $\mathrm{Ca}^{2+}$ regulating and $\mathrm{Ca}^{2+}$ regulated activities suggest significant original evolutionary inheritance of a remarkable inventory of molecules relevant for $\mathrm{Ca}^{2+}$ regulation.

\section{4. $\mathrm{Ca}^{2+}$ signalling in cells of modern era}

Can modern protists (protozoa and algae) provide clues to the evolution of $\mathrm{Ca}^{2+}$ signalling? As already mentioned, unikonts include myxamoebae (with Dictyostelium being the best known example [59]), and choanoflagellates, whereas bikonts are represented by alveolates, including ciliates like Paramecium and Tetrahymena. Experimental data on $\mathrm{Ca}^{2+}$ signalling are available for Dictyostelium and Paramecium [46]. Placing choanoflagellates at the roots of metazoan evolution [60] is based on a variety of molecular aspects, mainly Tyr phosphorylation and occurrence of cell adhesion molecules [61]. Whether and how these molecules bind extracellular $\mathrm{Ca}^{2+}$ remains to be clarified. Both ciliates and choanoflagellates, possess several $\mathrm{Ca}^{2+}$ influx channels, including transient receptor potential channels, cyclic nucleotide gated channels and voltage-gated channels. Remarkably ciliary localisation of voltage-dependent $\mathrm{Ca}^{2+}$ channels is also found in ctenophores [62].

$\mathrm{Ca}^{2+}$ is fundamental for regulation of multiple and distinct processes operating on widely different time scale not only in "higher" eukaryotes such as mammals [63], but also in protozoa. These cellular processes regulated by $\mathrm{Ca}^{2+}$ include gene transcription, exocytosis, endocytosis, vesicle trafficking, amoeboid movement and chemotaxis, ciliary and flagellar beat etc. When time domain is concerned, in ciliates $\mathrm{Ca}^{2+}$-regulated reactions can occur in submillisecond times in case of membrane fusion, in sub-second times in ciliary beat [64] and may also last hours in the regulation of gene transcription [65]. In subsequent sections we shall narrate a considerable congruence of different cell biological phenomena in low and high eukaryotes, respectively, with considerable deviations, however, in higher plants. A summary of certain important aspects is presented in Fig. 1.

\section{5. $\mathrm{Ca}^{2+}$ signalling toolkits in protozoa}

In the modern world $\mathrm{Ca}^{2+}$ normally occurs in sufficiently high concentration in the environment; $\mathrm{Ca}^{2+}$ concentration in the body fluids (that is extracellular $\mathrm{Ca}^{2+},\left[\mathrm{Ca}^{2+}\right]_{0}$ ) is also at the millimolar range being thus 20,000 times in excess over resting $\left[\mathrm{Ca}^{2+}\right]_{i}$ [5]. Ongoing diffusion through the plasmalemmal pores requires counter-regulation (i.e. $\mathrm{Ca}^{2+}$ efflux) in all cell types studied so far. Active transport by $\mathrm{Ca}^{2+}$-pumps and cation exchangers, possibly inherited from bacterial ancestors, execute this task. In all eukaryotes, a variety of plasmalemmal channels make $\mathrm{Ca}^{2+}$ available locally, but not distantly. Therefore, eukaryotic cells are additionally endowed with intracellular $\mathrm{Ca}^{2+}$ release channels, CRCs, pumps and antiporters localised to the membranes of $\mathrm{Ca}^{2+}$-storing organelles in animal $[33,44,66]$ and plant cells [51,52]. $\mathrm{Ca}^{2+}$ is contained not only in dedicated $\mathrm{Ca}^{2+}$ stores, such as the Endoplasmic and Sarcoplasmic Reticulum (ER/SR), but also in organelles of the different trafficking pathways. In essence, this arrangement is maintained throughout eukaryotic cell evolution.

\section{1. $\mathrm{Ca}^{2+}$ influx}

The spectrum of plasmalemmal $\mathrm{Ca}^{2+}$ influx channels, as well as of $\mathrm{Ca}^{2+}$ activated cation $\left(\mathrm{Na}^{+}, \mathrm{K}^{+}\right.$etc. $)$channels operating in the cell membrane steadily increases in evolution, from bacteria onwards [10]. There are considerable differences in $\mathrm{Ca}^{2+}$ channels between myxamoebae (Dictyostelium) and ciliates (Paramecium) [10]. The mechanosensitive cationic channels with $\mathrm{Ca}^{2+}$ permeability are present from bacteria to human, as are ligand-gated and voltagedependent $\mathrm{Ca}^{2+}$ channels. Specific subtypes of mechanosensitive channels are abundant in many of pathogenic protozoa, although Piezo subunits are not found in Apicomplexa [67], and yet they occur in the genome of related ciliates [68]. In many protozoa, including ciliates and parasites (Apicomplexa and Trypanosomatids), there is a diversified interaction between cyclic nucleotides and $\mathrm{Ca}^{2+}[69]$. Evidence for purinergic $\mathrm{Ca}^{2+}$-permeable channels is available from protozoa - in choanoflagellates and in Dictyostelium $[3,70]$. In Dictyostelium $\mathrm{Ca}^{2+}$ release by the $\mathrm{P}^{2} \mathrm{X}_{\mathrm{A}}$ channel mediates vesicle fusion at the level of the contractile vacuole [71]. Higher plants have mechanosensitive and nucleotide-gated channels [9] as well as ionotropic purinoceptors [72], but miss voltage-dependent $\mathrm{Ca}^{2+}$ channels $([73,53]$ this special issue). The higher up in the animal kingdom, the more differentiated become ligand-gated $\mathrm{Ca}^{2+}$ influx channels [74]. In summary, there is a variability of plasmalemmal $\mathrm{Ca}^{2+}$ channels depending on the systematic position of a species (for instance, significant differences are found between algae and flowering plants [73]), but some channels are preserved more or less throughout evolution.

\section{2. $\mathrm{Ca}^{2+}$ pumps}

The plasmamembrane $\underline{C a}^{2+}$-ATPase (PMCA) also known as plasmalemmal $\mathrm{Ca}^{2+}$ pump contributes to keep $\left[\mathrm{Ca}^{2+}\right]_{i}$ low despite permanent influx from the outside medium, as does the SERCA pump; both are P-type ATPases. Faster $\mathrm{Ca}^{2+}$ removal can be achieved by secondary active transporters, such as antiporter systems. Both primary and secondary active mechanisms of $\mathrm{Ca}^{2+}$ regulation are already known from bacteria, including SERCArelated pumps. The PMCA and SERCA are also present in protozoa being thus the old regulatory mechanisms maintained during evolution (Fig. 1). In Dictyostelium, according to sequencing data, a putative PMCA (pat1), $120 \mathrm{kDa}$ large, is reported to lack the typical calmodulin-binding domain [75]. Later sequence data suggested the presence of such a domain in three paralogues, including patA, although for all three isoforms localisation to the ER and/or the plasmamembrane has been left open [47]. The plasmalemmal presence, however, is supported by the colocalisation with calmodulin [75]. In Paramecium the PMCA is $\sim 130 \mathrm{kDa}$ in size and shows a conserved 21 aminoacids-long potential calmodulin-binding domain [76], in contrast to the SERCA of the same species [77]. Thus, despite some uncertainties in myxamoebae, it appears that $\mathrm{Ca}^{2+}$ extrusion and sequestration mechanisms are generally preserved over evolution. The PMCA-type pumps are operational not only in the cell membrane of animal cells, but also in flowering plants. The autoinhibitory domain of the PMCA is situated in the amino-terminal part in plants and in the carboxy-terminal part in mammals [78]. Deinhibition occurs by binding calmodulin. In plants, autoinhibited forms called ACA (for auto-inhibited $\mathrm{Ca}^{2+}$-ATPase), are slightly different and they occur not only in the plasmalemma but also in the vacuole membrane, also with a calmodulin-binding domain $([53,79,80]$ this special issue). During evolution, the inventory of pumps can be complemented by $\mathrm{Ca}^{2+}$-pyrophosphatase (CaPPase) in acidocalcisomes and in the contractile vacuole complex of some protozoa. This is of particular importance for protozoan parasites (see [81,82], this special issue). 


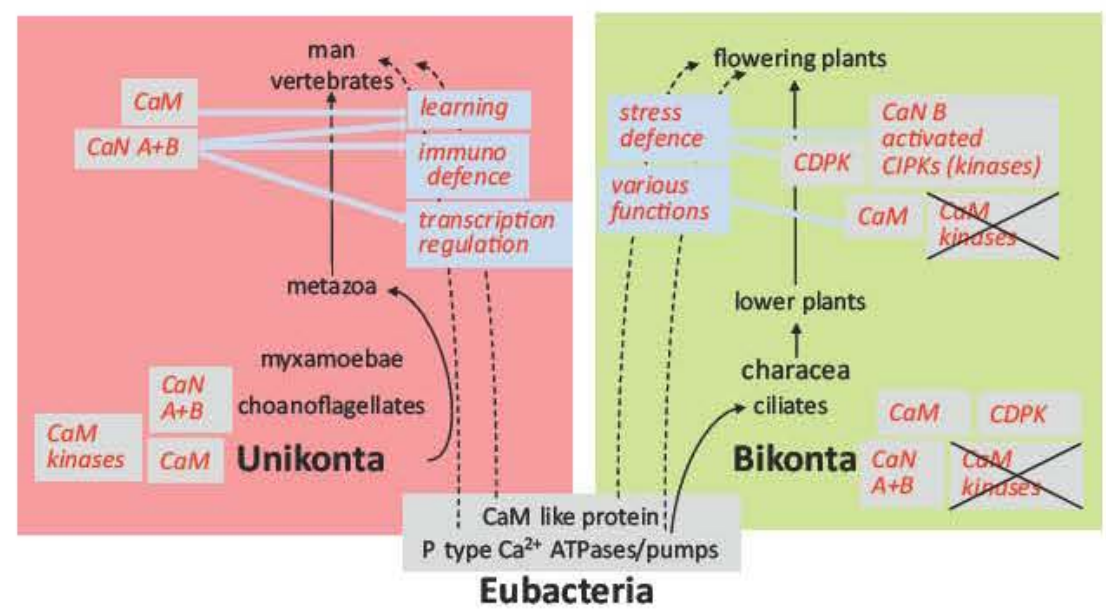

Fig. 1. This scheme highlights the transfer of some highly important molecules, or precursors thereof, through evolution, according to data cited in the text. It also reveals some essential differences between the two main lineages, Unikonta and Bikonta. P-type Ca ${ }^{2+}$-ATPases/pumps and calmodulin-like proteins are found already in bacteria. They are most elaborate already in protists of the mono- and bikont lineage. They acquire high significance on the way up to man where calmodulin regulates ion channels and the activity of the multifunctional dimeric protein phosphatase calcineurin (CaN). This in turn regulates gene transcription, immune defence and long term potentiation (learning). In higher plants, only the B subunit of calcineurin is maintained which regulates calcineurin B-activated protein kinases (CIPKs $=\underline{\mathrm{CBL}-i n t e r a c t i n g}$ protein kinases) in an extremely high number of combination of isoforms. The scheme also shows that ciliates and plants of different evolutionary level contain Ca ${ }^{2+}$-dependent protein kinases (CDPK, with integrated calmodulin-like EF-hand motifs), much more than - if any - $\mathrm{Ca}^{2+} /$ calmodulin-activated protein kinases (CaM kinases). Beyond that, in plants calmodulin also regulates many processes, some of which are plant specific.

\subsection{Exchangers}

Various $\mathrm{Ca}^{2+}$ exchangers are present from archaebacteria onwards [83], up to higher plants [51,52] and mammals [33]. In the absence of specific inhibitors, fictional expression of these exchangers is difficult to verify in protozoa; convincing evidence exists only for the different parasites ([81,82], this special issue). Antiporter systems for $\mathrm{Ca}^{2+}$ are frequently supported by a V-type $\mathrm{Ca}^{2+}$-ATPase/pump. Although little is known about antiporters in free-living protozoa and although in ciliates antiporters have not been identified at a molecular level, their occurrence can be derived from functional observations. When in Paramecium the V-type $\mathrm{H}^{+}$ATPase, a salient feature of the contractile vacuole/osmoregulatory complex, is blocked, $\left[\mathrm{Ca}^{2+}\right]_{i}$ recovery after stimulated $\mathrm{Ca}^{2+}$ increase is retarded by about 10 times [84] (in agreement with the permanent $\mathrm{Ca}^{2+}$ extrusion by the organelle) just as after knock-out of cortical centrin [85].

\subsection{Intracellular stores: Lumenal CaBPs}

Little is known about lumenal high capacity/low affinity CaBPs in vesicular stores of protists. Genes encoding calreticulin and calsequestrin have not been found in the Paramecium database, although there are some hints for their existence [86]. Difficulties in finding gene sequences (see [87], this special issue), can be explained by the abundance of acidic aminoacid residues, rather than of specific motifs [88]. However, the ER-resident forms, calreticulin and calnexin have been identified in the database of Dityostelium, where knockout experiments resulted in inhibition of phagocytosis [89]. In that latter study, calreticulin sequences were also detected in Trypanosoma and Leishmania.

\subsection{Intracellular stores: InsP $P_{3} R / R y R$ calcium release channels}

The inositol 1,4,5-trisphosphate $\left(\mathrm{InsP}_{3}\right) \mathrm{Ca}^{2+}$ release channels generally referred to as Ins $\mathrm{P}_{3}$ receptors (Ins $\mathrm{P}_{3} \mathrm{Rs}$ ) have been identified in genomic studies in Dictyostelium [90] and in the choanoflagellate, Monosiga $[61,91]$. Although not studied in detail at the molecular level, Ins $\mathrm{P}_{3} \mathrm{R}$ null-mutants of Dictyostelium are available and, thus, $\operatorname{InsP}_{3}$ was shown to contribute to the motility responses to shear stress, together with $\mathrm{Ca}^{2+}$ influx activated by trimeric G-protein [92]. In Paramecium, genomic analysis revealed InsP $\mathrm{P}_{3} \mathrm{Rs}$ [93], and a second type of CRC resembling a ryanodine receptor (RyR), defined as RyR-LPs [94], or CRCs with mixed features $([45,87,95]$ this special issue). When compared with their mammalian counterparts [96,97] RyR-LPs of Paramecium were remarkably different in size [45]. Two of Paramecium CRCs have been thoroughly characterised at a cellular and functional level, including Ins $\mathrm{P}_{3}$ binding [93] and stimulation with RyR agonists [94]. Genomic analysis of Monosiga supports the presence of InsP $\mathrm{P}_{3} \mathrm{Rs}$, whereas sequences indicating RyRs are detected only for Salpingoeca ([48], this special issue). Sequences with variable similarity can be found in the genetic databases of different organisms, even where such CRCs have not been described in any more detail $[94,98]$. However, this aspect has to be considered with caution before any proteomic and functional analyses are made.

Although it is impossible to extrapolate to the Ur-eukaryote, identification of both these CRC types and intermediates in ciliates, led to an assumption of a common ancestor of both, InsP $\mathrm{P}_{3} \mathrm{R}$ and a RyRs already at the level of protozoa [94,98]. According to genomic analyses, also in choanoflagellates, the most important CRCs have been formed very early, similarly to ciliates. This includes not only Ins $\mathrm{P}_{3} \mathrm{R}$ and possibly also homologues of RyRs, but also two-pore channels, TPCs ([48], this special issue). In evolution, plants either have never acquired, or lost all these channels ([53], this special issue). A common ancestral channel for both, InsP ${ }_{3}$ Rs and RyRs, has been proposed particularly based on similar size, on the pore domain with six transmembrane domains, and the aminoacid signature within its selectivity filter [94,98].

\subsection{Other CRCs and additional $\mathrm{Ca}^{2+}$ stores}

The complexity of $\mathrm{Ca}^{2+}$ stores and $\mathrm{Ca}^{2+}$ release channels may be further complemented by additional organelles capable of storing $\mathrm{Ca}^{2+}$ and by additional $\mathrm{Ca}^{2+}$ release channels, which were observed already in unicellular organisms. Additional $\mathrm{Ca}^{2+}$ stores, such as acidocalcisomes, have been recently discovered in various protozoa including Dictyostelium [99], in flagellate parasites, as well as in human $([81,100]$, this special issue). The big vacuole of higher plants may be similarly considered as a $\mathrm{Ca}^{2+}$ storage organelle. 
There is indirect evidence from microinjection studies that some metabolites, such as CADPR and NAADP known to release $\mathrm{Ca}^{2+}$ from intracellular stores in higher eukaryotes are also effective in triggering $\mathrm{Ca}^{2+}$ release in Paramecium [84]. The cADPR is discussed as the physiological activator of RyRs [101], whereas NAADP activates two-pore-channels (TPCs) in acidic compartments [102,103], such as lysosomal and endosomal compartments in mammalian cells [104]. Although TPCs have not been hitherto identified in ciliates at a molecular level, their presence can be expected from the binding of NAADP with a $K_{\mathrm{D}}$ of $3.3 \mathrm{nM}$ [84] and the reaction of cells to microinjected NAADP [105]; see also ref. [106], this special issue.

Several types of $\mathrm{Ca}^{2+}$ channels disappeared and some were newly formed during evolution. $\mathrm{Ca}^{2+}$ is involved in several steps of chemotaxis and a variety of $\mathrm{Ca}^{2+}$-dependent key molecules are conserved from Dictyostelium to human [107]. In Dictyostelium, as mentioned, putative InsP $\mathrm{P}_{3}$ Rs may contribute to the motility in response to shear flow [92]. In the myxamoebae, certain sequences suggest the appearance of additional putative CRCs, of mucolipin type (late endosomes/lysosomes), or polycystin-2 type (these being equivalent to polycystin cation channel PKD2) or TRPP2 and a TPC in the contractile vacuole complex $[47,108]$. The PKD2 serves for the perception of fluid flow [108]. In Dictyostelium, $\mathrm{Ca}^{2+}$ permeable purinoceptors of P2X type, serve as CRCs localised to the contractile vacuole complex $[71,109]$ where they modulate osmoregulation [110]. In plants, InsP $\mathrm{P}_{3}$ Rs and TRPs seem to have disappeared ([53], this special issue). TRPs and TPC channels have not been found in ciliate databases [111] although there are functional hints to support functional expression of TPCs, as outlined above.

Besides dedicated $\mathrm{Ca}^{2+}$ stores (ER, SR), many trafficking organelles (endosomes, lysosomes, phagosomes and some secretory organelles) also contain $\mathrm{Ca}^{2+}[112]$. This organelles are likely to facilitate local signalling for vesicle interaction and fusion. Not only InsP ${ }_{3}$ Rs and RyRs may be involved, but also some other types of CRCs. A characteristic example is $\mathrm{Ca}^{2+}$ release by a P2X purinoceptors contained in the contractile vacuole membrane of Dictyostelium at the contact site to the cell membrane where both membrane fuse by exocytosis for contents release [71]. The principle of heterogeneous distribution of CRCs between different $\mathrm{Ca}^{2+}$ storing organelles is realised also with other proteins relevant for trafficking [87,95]. For instance, acidification can determine targeting by a trans-membrane signal through a conformational change of the V-type $\mathrm{H}^{+}$-ATPase complex and ensuing attachment of RabGTPase modulating proteins [113]; similarly a targeting sequence in human TPC2 interacts with Rab GTPases [114]. Escorters of different kinds can also achieve selective deposition of membrane proteins relevant for $\mathrm{Ca}^{2+}$ signalling (see [115] for details).

\subsection{Release channels in other Bikonta}

How is $\mathrm{Ca}^{2+}$ handled in green plants, from algae to angiosperms? In flagellated algae, such as Euglena gracilis [116], and in the complex alga, Chara [117], positioned at the roots of multicellular plant evolution, as well as in higher plants, InsP $\mathrm{P}_{3} \mathrm{R}$ effects have been experimentally detected. In Euglena, cADPR applied to subcellular fractions was also effective [116], but no RyR-type channels have been detected so far. This is in line with electrophysiological recordings with reconstituted membranes isolated from the Bryonia plant (climbing on bushes in central Europe, [118]) and with biochemical studies with vacuolar membranes isolated from cauliflower [119]. Nevertheless, neither $\mathrm{InsP}_{3} \mathrm{Rs}$, nor voltagegated $\mathrm{Ca}^{2+}$ channels nor TRP channels were identified in plants, in contrast to mechanosensitive, ATP-gated P2X-like purinoceptors, cyclic nucleotide-gated and two-pore channels ([53,72,73], this special issue).

In essence, InsP $\mathrm{P}_{3} \mathrm{Rs}$ are widely distributed in lower eukaryotes (though not in all), where RyRs also appear in the form of RyR-LPs, as documented for Paramecium. In contrast, such channels could not be ascertained in higher-level bikonts, such as plants.

Most recently, molecular and bioinformatic analysis of representatives of unikonts and bikonts revealed the presence of $\mathrm{Ca}^{2+} / \mathrm{H}^{+}$ exchangers and of TPCs in both groups ([48], this special issue). This also includes a complex flagellar $\mathrm{Ca}^{2+}$ channel, CatSper, initially discovered as a sperm-specific cation channel responsible for motile activity of spermatozoa [120]. These molecules, therefore, seem to belong to a common original heritage. Analysis of a primitive bikont, Aurantiochytrium limacinum revealed, in addition, sequences of voltage-gated $\mathrm{Ca}^{2+}$ influx channels, $\mathrm{InsP}_{3} \mathrm{Rs}$ (though functionally not tested), $\mathrm{Ca}^{2+}$ exchangers, purinergic receptors, TPCs, TRPCs, MCU and regulator MICU, in addition to PMCA and SERCA ([48], this special issue). These are promising predictions, which however, require further scrutiny.

\subsection{Store-operated $\mathrm{Ca}^{2+}$ entry}

Release of $\mathrm{Ca}^{2+}$ from intracellular stores, with their consequent depletion, in many types of mammalian cells induces the store-operated $\mathrm{Ca}^{2+}$ entry, SOCE [121], initially defined as a capacitative $\mathrm{Ca}^{2+}$ entry [122]. The content of the ER store is monitored by the endomembrane protein, stromal interacting molecule (Stim), which, upon store depletion, oligomerises, migrates to ERplasmalemmal junctions and opens the $\mathrm{Ca}^{2+}$-release-activated $\mathrm{Ca}^{2+}$ (CRAC) channels assembled from Orai proteins [123,124]. None of these molecules have been detected in Paramecium [46]. Only in some algae sequences indicative of Orai have been found, whereas choanoflagellates possess Orai and Stim; none of them occurs in Arabidopsis and in Dictyostelium or the protozoa whose database has been evaluated ([48,111], this special issue). The SOCE can be also mediated by plasmalemmal TRP channels that can be, arguably, activated by oligomerised Stim [125,126]. The TRP channels are represented by five metazoan forms, which exist already in the genome of choanoflagellates [127] and are highly diversified in further evolution to mammals [128].

A store-operated $\mathrm{Ca}^{2+}$ entry, however, is operational in Paramecium [129], where it is linked to a $\mathrm{Ca}^{2+}$ release mediated by RyR-like channels [46]. Considering the manifold types of ER-cell membrane connections that become increasingly known [130-133], a functional equivalent of Orai/Stim may not be required for the coupling of cortical stores with the plasma membrane in lower eukaryotes providing other proteins take over this function. In Dictyostelium the situation seems to be different. Here, a CICR was reported to be coupled to contractile vacuole (an acidic compartment) activity as analysed in a mutant devoid of the putative $\operatorname{InsP}_{3} \mathrm{R}$ [134]. It would be interesting to see whether a NAADP signalling pathway could be involved here. In summary, plasmalemmal $\mathrm{Ca}^{2+}$ influx coupled to store activation via SOCE or perhaps also to CICR (if verified) appear evolutionary old mechanisms.

\section{Evolution of $\mathrm{Ca}^{2+}$ binding proteins}

Bacteria contain many CaBPs or their elements found also in eukaryotes (Fig. 1), including for example a calmodulin-like protein present in eubacteria. This and other bacterial CaBPs all contain EFhand motif $[16,49]$, thus suggesting a conserved role for EF-hand CaBPs throughout evolution all the way to flowering plants [80] and mammals [135]. At the same time the data on bacterial expression of centrin (also with EF-hand motives, [136]) or CaBPs with C2 domains are missing. Centrin is present from protozoa, including ciliates [137] to human and from Chlamydomonas to angiosperms [138,139a].

In animals, the number of EF-type CaBPs exceeds C2-domain CaBPs by 3 times, but only by about two times in plants $[16,49]$. 
The CaBPs with two C2 domains, as present in synaptotagmin of metazoans, are not known from protozoa, but they occur in plants [139b]. In animals, synaptotagmin is the metazoan $\mathrm{Ca}^{2+}$ sensor required for membrane fusion. By its fast conformational change synaptotagmin allows for rapid membrane fusion during exocytosis [140,141], as well as during endocytosis [142]. In Paramecium, the only comparable protein with eight $\mathrm{C} 2$ domains can be detected in the database (R. Kissmehl and H. Plattner unpublished observations) although the exocytosis in this species is very fast [64]. Similar proteins, called extended (E-) synaptotagmins, with up to six C2 domains have been detected also in mammalian cells where they can substitute for synaptotagmin for rapid vesicle fusion $[143,144]$. As in other protozoa, proteins with C2 domains [145] remain to be scrutinised also in Dictyostelium. In mammalian cells, exocytosis kinetics differs substantially between cell types [146,147], which can be possibly associated with different sensors [144]. In summary, scarce information about C2-type $\mathrm{Ca}^{2+}$ sensors in lower eukaryotes entails the salient question: How is membrane fusion mediated in these cells?

In summary, calmodulin contributes to the assembly of exocytotic membrane fusion sites from protozoa [148] to mammals $[149,150]$. Similarly, from protozoa onwards calmodulin activates the PMCA, although reportedly not in all species, as discussed above. Centrin expression is well established in protozoa; in Paramecium for instance, binding of $\mathrm{Ca}^{2+}$ to cortical centrin after strong stimulation of exocytosis is sufficiently fast and efficient to provide for fast $\left[\mathrm{Ca}^{2+}\right]_{i}$ recovery $[85]$.

Copines and annexins represent additional groups of CaBPs, either with $\mathrm{C} 2$ or with alternative $\mathrm{Ca}^{2+}$ binding motifs. After detection in Paramecium [151] copines were found ubiquitously, from Dictyostelium [152] and Arabidopsis [153] up to the mammalian brain [154]. By their C2 domains copines bind to membranes in $\mathrm{Ca}^{2+}$-dependent manner and, hence, may contribute to vesicle trafficking [153]. Annexins are widely distributed $\mathrm{Ca}^{2+} /$ phospholipid binding proteins with typical domains, of neither of the EF- nor of the C2-type [155]. For coordinative $\mathrm{Ca}^{2+}$ binding only smaller stretches are available. After a long debate about the fusogenicity of annexins, e.g. during exocytosis, they are now considered as membrane-to-membrane links [155].

In summary, the substantial inventory of CaBPs in bacteria and protozoa provide a background for considerable increase in higher plants and animals. However, in protozoa, $\mathrm{Ca}^{2+}$ sensors mediating membrane fusion remain to be characterised.

\section{An evolutionary selection for $\mathrm{Ca}^{2+}$ sensors}

All eukaryotic cells contain enzymes regulated by $\mathrm{Ca}^{2+}$ binding. The Dictyostelium kinome contains a battery of $\mathrm{Ca}^{2+} /$ calmodulindependent kinases ("CaM-kinases") [156]. The ciliates [157], their relatives (Apicomplexa, e.g. Plasmodium) [158] as well as plants from green algae to land plants $[159,160]$ all express $\mathrm{Ca}^{2+}$-dependent protein kinases (CDPK), which contain an integrated calmodulin-like domain, rather than binding a free $\mathrm{Ca}^{2+} /$ calmodulin complex, as is the case for CaM-kinases in higher animal cells. From chlorophyceae (Chlamydomonas) to angiosperms the CDPK family is broadly represented [161] particularly in the course of transition to terrestrial life where it supports developmental processes and stress resistance [160]. Modern flowering plants also contain a genuine "CaM kinase" or $\mathrm{Ca}^{2+} /$ calmodulin activated protein kinase ([53], this special issue).

Other $\mathrm{Ca}^{2+}$ sensor functions include calcineurin (protein phosphatase 2B, PP2B) which, during animal evolution, has developed a signalling network based on conserved substrate motifs [162]. In mammals, calcineurin is involved in immune defence by activating transcription factor NFAT during T-cell activation as well as in long-term potentiation in Purkinje neurones [163]. Calcineurin also appears in myxamoebae [164] where it regulates development and differentiation. Dictyostelium and Paramecium contain both subunits of calcineurin, A and B $[165,166]$, as is the case with other protozoa [166]. In flowering plants, only the regulatory $\mathrm{Ca}^{2+}$ binding subunit B is found; it serves for stress defence (Fig. 1; $[53,159]$, this special issue). Thus, calcineurin/PP2 is another system developed at early stages of $\mathrm{Ca}^{2+}$ signalling and maintained up to the very top of the evolutionary ladder. Being a CaBP itself, it also regulates $\mathrm{Ca}^{2+}$ dynamics, for example SOCE, via Orai and Stim [167]. Homer is another protein maintained from the choanoflagellate precursors of metazoans on [168]. In mammalian nervous system Homer serves as a scaffold for the formation of postsynaptic densities; remarkably, in choanoflagellates and in metazoan astrocytes it resides in the nucleus as a Homer/Flotillin (Reggie) complex [168].

\section{Special aspects in apicomplexan parasites and plants}

\subsection{The parasites}

Parasites are notorious for evolving survival strategies. It appears that apicomplexan parasites (Plasmodium and Toxoplasma), close relatives of ciliates [36,158], have functionally transformed the equivalent of the alveolar sacs from a $\mathrm{Ca}^{2+}$ store in ciliates to the "inner membrane complex" which, in contrast to alveoloar sacs of Paramecium, have extremely low (i.e. below detection threshold) $\mathrm{Ca}^{2+}$ concentration [84]. These organelles are, arguably, dedicated to the mechanics of host cell penetration, rather than serving as a $\mathrm{Ca}^{2+}$ store $[84,169]$; the infectious attack is facilitated by the release of nearby docked dense core-secretory vesicles, rhoptries and micronemes (remotely resembling Paramecium's trichocysts). Consequently, these parasites rely on other $\mathrm{Ca}^{2+}$ stores (Lourido and Moreno [82] this special issue). Though $\operatorname{InsP}_{3}$ effects relevant for $\mathrm{Ca}^{2+}$ signalling and host cell interaction have been established [170-172], the InsP $\mathrm{P}_{3}$ Rs have not yet been identified $[45,173]$. In contrast, molecular and functional identification of InsP $\mathrm{P}_{3}$ Rs has been achieved in other protozoa of the bikont branch, the parasitic flagellates, Trypanosoma brucei [174] and Trypanosoma cruzi [175]. In T. brucei, InsP ${ }_{3}$ Rs have been shown to be located in the acidocalcisome membrane ([81], this special issue).

\subsection{Comparison with higher bikonts, the plants}

Handling of, and signalling by $\mathrm{Ca}^{2+}$ in the immobile green plants differs considerably from that in animals. Ecological aspects, such as selection of non-calciferous locations, as well as gross regulatory mechanisms, for example release of an excess of $\mathrm{Ca}^{2+}$ ions by guttation from leaves, can help the plant cell to avoid stress. Limiting stress also requires regulation of $\mathrm{Ca}^{2+}$ at a cellular level [51]. Stress defence activates a system of CBL-interacting protein kinases (CIPKs) that are activated by calcineurin B [176,177], the regulatory subunit containing a $\mathrm{Ca}^{2+}$ binding site. In plant cell membrane and in the membrane of the big vacuole, primary active and secondary active transport processes occur through exchangers connected to the $\mathrm{H}^{+}$-ATPase/pump. Here the most extensive diversification of calcineurin B-LPs (CBL) is observed; the CBL in conjunction with CIPKs, regulate many functions of the vacuole and of the plasma membrane [178]. No intracellular CRCs of the $\mathrm{InsP}_{3} \mathrm{R} / \mathrm{RyR}$ supergroup have been unambiguously demonstrated in plants although some reports advocated for InsP $\mathrm{P}_{3}$ Rs-related physiological effects, as discussed above. In contrast, numerous influx channels and CaBPs have been identified in plants ([53], this special issue). Essentially plants may have lost InsP $\mathrm{P}_{3} \mathrm{Rs}$ as well as voltagegated and TRP channels [73] using other channels instead. 


\section{3. $\mathrm{Ca}^{2+}$ signalling and transition to multicellularity}

Transition to multicellularity called for cell adhesion proteins, including $\mathrm{Ca}^{2+}{ }_{0}$-dependent cadherins or their predecessors. The attachment of Dictyostelium to the substrate, similarly to mammalian cells, requires $\mathrm{Ca}^{2+}[92]$. Cadherins are absent from Dictyostelium and their capability to form a multicellular stalk has another molecular basis [179]. The choanoflagellates genomic data mining suggests cadherin-based cell-to-cell connections ([60], and [48] this special issue). Proteins involved in intercellular contact formation during conjugation in ciliates are not related to metazoan cell adhesion molecules [180]. Cadherins were maintained throughout metazoan evolution, but have not been found in plant databases [181]. This indicates a clear separation between unikont and bikont organisms.

\section{Conclusions}

Fundamental elements of cellular $\mathrm{Ca}^{2+}$ homeostasis and $\mathrm{Ca}^{2+}$ signalling are conserved from bacteria to human. These include $\mathrm{Ca}^{2+}$-pumps and exchangers, $\mathrm{Ca}^{2+}$ influx channels as well as some CaBPs, such as calmodulin, which all are present in prokaryotes. The $\mathrm{Ca}^{2+} /$ calmodulin-activated protein phosphatase PP2B (calcineurin) is engaged in manifold signalling from different protozoa up to human where it regulates complex functions, such as immunedefence and long term potentiation [182]. However, some gaps in knowledge remain; for instance there is a discrepancy between overt InsP $\mathrm{P}_{3}$ effects observed and the failure to identify $\operatorname{InsP}_{3} \mathrm{R}$ type genomic sequences in some organisms. The recent focus on choanoflagellates as ancestors of metazoans calls for the extension of molecular biology data to cell physiology. Interpretation of sequences in an evolutionary context can also be hampered by horizontal, and possibly also by vertical gene transfer that is common among protozoa [183]. Nevertheless, many data on $\mathrm{Ca}^{2+}$ signalling throughout evolution yield a quite consistent picture (Fig. 1). The present issue of Cell Calcium presents an interim balance.

\section{Acknowledgements}

The work of H.P. cited herein has been supported by the German Research Council. A.V. was supported by the Wellcome Trust, by Alzheimer's research foundation (UK) and by the grant (agreement from August 272013 no. 02.B.49.21.0003) between The Ministry of Education and Science of the Russian Federation and Lobachevsky State University of Nizhny Novgorod and by the grant of the Russian Scientific Foundation no. 14-15-00633.

\section{References}

[1] J. Kazmierczak, S. Kempe, B. Kremer, Calcium in the early evolution of living systems: a biohistorical approach, Curr. Org. Chem. 17 (2013) 1738-1750.

[2] N.W. Blackstone, The impact of mitochondrial endosymbiosis on the evolution of calcium signaling, Cell Calcium 57 (2015) 133-139.

[3] A. Verkhratsky, G. Burnstock, Biology of purinergic signalling: its ancient evolutionary roots, its omnipresence and its multiple functional significance, Bioessays 36 (2014) 697-705.

[4] I. Torrecilla, F. Leganes, I. Bonilla, F. Fernandez-Pinas, Use of recombinant aequorin to study calcium homeostasis and monitor calcium transients in response to heat and cold shock in cyanobacteria, Plant Physiol. 123 (2000) $161-176$.

5] R.M. Case, D. Eisner, A. Gurney, O. Jones, S. Muallem, A. Verkhratsky, Evolution of calcium homeostasis: from birth of the first cell to an omnipresent signalling system, Cell Calcium 42 (2007) 345-350.

[6] D.C. Domínguez, Calcium signalling in bacteria, Mol. Microbiol. 54 (2004) 291-297.

[7] K. Faxén, J.L. Andersen, P. Gourdon, N. Fedosova, J.P. Morth, P. Nissen, JV. Mller, Characterization of a Listeria monocytogenes $\mathrm{Ca}^{2+}$ pump: a SERCAtype ATPase with only one $\mathrm{Ca}^{2+}$-binding site, J. Biol. Chem. 286 (2011) 1609-1617.
[8] L. Raeymaekers, E. Wuytack, I. Willems, C.W. Michiels, F. Wuytack, Expression of a P-type $\mathrm{Ca}^{2+}$-transport ATPase in Bacillus subtilis during sporulation, Cell Calcium 32 (2002) 93-103

[9] M.E. Wilson, G. Maksaev, E.S. Haswell, MscS-like mechanosensitive channels in plants and microbes, Biochemistry 52 (2013) 5708-5722.

[10] B. Martinac, Y. Saimi, C. Kung, Ion channels in microbes, Physiol. Rev. 88 (2008) 1449-1490.

[11] D.C. Domínguez, M. Guragain, M. Patrauchan, Calcium binding proteins and calcium signaling in prokaryotes, Cell Calcium 57 (2015) 151-165.

[12] V. Norris, S. Grant, P. Freestone, J. Canvin, F.N. Sheikh, I. Toth, M. Trinei, K. Modha, R.I. Norman, Calcium signalling in bacteria, J. Bacteriol. 178 (1996) 3677-3682.

[13] D.G. Swan, R.S. Hale, N. Dhillon, P.F. Leadlay, A bacterial calcium-binding protein homologous to calmodulin, Nature 329 (1987) 84-85.

[14] K. Yang, Prokaryotic calmodulins: recent developments and evolutionary implications, J. Mol. Microbiol. Biotechnol. 3 (2001) 457-459.

[15] T. Yonekawa, Y. Ohnishi, S. Horinouchi, A calmodulin-like protein in the bacterial genus Streptomyces, FEMS Microbiol. Lett. 244 (2005) 315-321.

[16] R.J. Williams, The evolution of calcium biochemistry, Biochim. Biophys. Acta 1763 (2006) 1139-1146.

[17] E.R. Chapman, How does synaptotagmin trigger neurotransmitter release? Annu. Rev. Biochem. 77 (2008) 615-641.

[18] T. Cavalier-Smith, The neomuran origin of archaebacteria, the negibacterial root of the universal tree and bacterial megaclassification, Int. J. Syst. Evol. Microbiol. 52 (2002) 7-76.

[19] S. Gribaldo, C. Brochier-Armanet, The origin and evolution of archaea: a state of the art, Philos. Trans. R. Soc. Lond. B: Biol. Sci. 361 (2006) 1007-1022.

[20] A. Spang, J. Martijn, J.H. Saw, A.E. Lind, L. Guy, T.J. Ettema, Close encounters of the third domain: the emerging genomic view of archaeal diversity and evolution, Archaea 2013 (2013) 202358

[21] L. Eme, S.C. Sharpe, M.W. Brown, A.J. Roger, On the age of eukaryotes: evaluating evidence from fossils and molecular clocks, Cold Spring Harb. Perspect. Biol. 6 (2014) a016139.

[22] A.H. Knoll, Paleobiological perspectives on early eukaryotic evolution, Cold Spring Harb. Perspect. Biol. 6 (2014) a016121.

[23] L.W. Parfrey, D.J. Lahr, A.H. Knoll, L.A. Katz, Estimating the timing of early eukaryotic diversification with multigene molecular clocks, Proc. Natl. Acad. Sci. U. S. A. 108 (2011) 13624-13629.

[24] B. Rasmussen, I.R. Fletcher, J.J. Brocks, M.R. Kilburn, Reassessing the first appearance of eukaryotes and cyanobacteria, Nature 455 (2008) 1101-1104.

[25] J.J. Brocks, G.A. Logan, R. Buick, R.E. Summons, Archean molecular fossils and the early rise of eukaryotes, Science 285 (1999) 1033-1036.

[26] H.D. Pflug, Early diversification of life in the Archean, Zbl. Bakt. Hyg. I Abt. Orig. C3 (1982) 611-615.

[27] H. Hartman, A. Fedorov, The origin of the eukaryotic cell: a genomic investigation, Proc. Natl. Acad. Sci. U. S. A. 99 (2002) 1420-1425.

[28] D.P. Devos, R. Gräf, M.C. Field, Evolution of the nucleus, Curr. Opin. Cell Biol. 28 (2014) 8-15.

[29] P. Forterre, The common ancestor of archaea and eukarya was not an archaeon, Archaea 2013 (2013) 372396.

[30] J.B. Dacks, M.C. Field, Evolution of the eukaryotic membrane-trafficking system: origin, tempo and mode, J. Cell Sci. 120 (2007) 2977-2985.

[31] M. Elias, Patterns and processes in the evolution of the eukaryotic endomembrane system, Mol. Membr. Biol. 27 (2010) 469-489.

[32] J.K. Jaiswal, Calcium - how and why? J. Biosci. 26 (2001) 357-363.

[33] M.J. Berridge, P. Lipp, M.D. Bootman, The versatility and universality of calcium signalling, Nat. Rev. Mol. Cell Biol. 1 (2000) 11-21.

[34] M. Yáñez, J. Gil-Longo, M. Campos-Toimil, Calcium binding proteins, Adv. Exp. Med. Biol. 740 (2012) 461-482.

[35] S.M. Adl, A.G. Simpson, M.A. Farmer, R.A. Andersen, O.R. Anderson, J.R. Barta, S.S. Bowser, G. Brugerolle, R.A. Fensome, S. Fredericq, T.Y. James, S. Karpov, P. Kugrens, J. Krug, C.E. Lane, L.A. Lewis, J. Lodge, D.H. Lynn, D.G. Mann, R.M. McCourt, L. Mendoza, O. Moestrup, S.E. Mozley-Standridge, T.A. Nerad, C.A. Shearer, A.V. Smirnov, F.W. Spiegel, M.F. Taylor, The new higher level classification of eukaryotes with emphasis on the taxonomy of protists, J. Eukaryot. Microbiol. 52 (2005) 399-451.

[36] S.M. Adl, A.G. Simpson, C.E. Lane, J. Lukes, D. Bass, S.S. Bowser, M.W. Brown, F. Burki, M. Dunthorn, V. Hampl, A. Heiss, M. Hoppenrath, E. Lara, L. Le Gall, D.H. Lynn, H. McManus, E.A. Mitchell, S.E. Mozley-Stanridge, L.W. Parfrey, J. Pawlowski, S. Rueckert, R.S. Shadwick, C.L. Schoch, A. Smirnov, F.W. Spiegel, The revised classification of eukaryotes, J. Eukaryot. Microbiol. 59 (2012) 429-493.

[37] E.J. Douzéry, E.A. Snell, E. Bapteste, F. Delsuc, H. Philippe, The timing of eukaryotic evolution: does a relaxed molecular clock reconcile proteins and fossils? Proc. Natl. Acad. Sci. U. S. A. 101 (2004) 15386-15391.

[38] S.L. Baldauf, W.F. Doolittle, Origin and evolution of the slime molds (Mycetozoa), Proc. Natl. Acad. Sci. U. S. A. 94 (1997) 12007-12012.

[39] J.A. Doyle, Molecular and fossil evidence on the origin of angiosperms, Annu. Rev. Earth Planet. Sci. 40 (2012) 301-326.

[40] T.H. Kloepper, C.N. Kienle, D. Fasshauer, SNAREing the basis of multicellularity: consequences of protein family expansion during evolution, Mol. Biol. Evol. 25 (2008) 2055-2068 
[41] H. Stenmark, The Rabs: a family at the root of metazoan evolution, BMC Biol. 10 (2012) 68

[42] A.M. Rojas, G. Fuentes, A. Rausell, A. Valencia, The Ras protein superfamily: evolutionary tree and role of conserved amino acids, J. Cell Biol. 196 (2012) 189-201.

[43] A. Verkhratsky, O.H. Petersen, The endoplasmic reticulum as an integrating signalling organelle: from neuronal signalling to neuronal death, Eur. J. Pharmacol. 447 (2002) 141-154.

[44] A. Verkhratsky, Physiology and pathophysiology of the calcium store in the endoplasmic reticulum of neurons, Physiol. Rev. 85 (2005) 201-279.

[45] E.M. Ladenburger, H. Plattner, Calcium-release channels in Paramecium. Genomic expansion, differential positioning and partial transcriptional elimination, PLoS ONE 6 (2011) e27111.

[46] H. Plattner, Calcium regulation in the protozoan model, Paramecium tetraurelia, J. Eukaryot. Microbiol. 61 (2014) 95-114

[47] Z. Wilczynska, K. Happle, A. Müller-Taubenberger, C. Schlatterer, D. Malchow, P.R. Fisher, Release of $\mathrm{Ca}^{2+}$ from the endoplasmic reticulum contributes to $\mathrm{Ca}^{2+}$ signaling in Dictyostelium discoideum, Eukaryot. Cell 4 (2005) $1513-1525$.

[48] X. Cai, X. Wang, S. Patel, D.E. Clapham, Insights into the early evolution of animal calcium signalling machinery: a unicellular point of view, Cell Calcium 57 (2015) 166-173.

[49] R.O. Morgan, S. Martin-Almedina, J.M. Iglesias, M.I. Gonzalez-Florez, M.P. Fernandez, Evolutionary perspective on annexin calcium-binding domains, Biochim. Biophys. Acta 1742 (2004) 133-140.

[50] L.P. Haynes, H.V. McCue, R.D. Burgoyne, Evolution and functional diversity o the calcium binding proteins (CaBPs), Front. Mol. Neurosci. 5 (2012) 9

[51] A.N. Dodd, J. Kudla, D. Sanders, The language of calcium signaling, Annu. Rev. Plant Biol. 61 (2010) 593-620.

[52] P.J. White, M.R. Broadley, Calcium in plants, Ann. Bot. 92 (2003) 487-511.

[53] K.H. Edel, J. Kudla, Increasing complexity and versatility: how the calcium signaling toolkit was shaped during plant land colonization, Cell Calcium 57 (2015) 231-246.

[54] W. Martin, M. Mentel, The origin of mitochondria, Nat. Educ. 3 (2010) 58.

[55] J.K. Foskett, M. Madesh, Regulation of the mitochondrial $\mathrm{Ca}^{2+}$ uniporter by MICU1 and MICU2, Biochem. Biophys. Res. Commun. 449 (2014) 377-383.

[56] R.M. Denton, Regulation of mitochondrial dehydrogenases by calcium ions, Biochim. Biophys. Acta 1787 (2009) 1309-1316

[57] A.G. Bick, S.E. Calvo, V.K. Mootha, Evolutionary diversity of the mitochondria calcium uniporter, Science 336 (2012) 886.

[58] Y. Sancak, A.L. Markhard, T. Kitami, E. Kovacs-Bogdan, K.J. Kamer, N.D. Udeshi, S.A. Carr, D. Chaudhuri, D.E. Clapham, A.A. Li, S.E. Calvo, O. Goldberger, V.K. Mootha, EMRE is an essential component of the mitochondrial calcium uniporter complex, Science 342 (2013) 1379-1382.

[59] A. Müller-Taubenberger, A. Kortholt, L. Eichinger, Simple system - substantial share: the use of Dictyostelium in cell biology and molecular medicine, Eur. J. Cell Biol. 92 (2013) 45-53.

[60] S.A. Nichols, B.W. Roberts, D.J. Richter, S.R. Fairclough, N. King, Origin of metazoan cadherin diversity and the antiquity of the classical cadherin/beta-catenin complex, Proc. Natl. Acad. Sci. U. S. A. 109 (2012) 13046-13051.

[61] N. King, M.J. Westbrook, S.L. Young, A. Kuo, M. Abedin, J. Chapman, S. Fairclough, U. Hellsten, Y. Isogai, I. Letunic, M. Marr, D. Pincus, N. Putnam, A Rokas, K.J. Wright, R. Zuzow, W. Dirks, M. Good, D. Goodstein, D. Lemons, W Li, J.B. Lyons, A. Morris, S. Nichols, D.J. Richter, A. Salamov, J.G. Sequencing, P. Bork, W.A. Lim, G. Manning, W.T. Miller, W. McGinnis, H. Shapiro, R. Tjian, I.V. Grigoriev, D. Rokhsar, The genome of the choanoflagellate Monosiga brevicollis and the origin of metazoans, Nature 451 (2008) 783-788

[62] L.L. Moroz, K.M. Kocot, M.R. Citarella, S. Dosung, T.P. Norekian, I.S. Povolotskaya, A.P. Grigorenko, C. Dailey, E. Berezikov, K.M. Buckley, A. Ptitsyn, D. Reshetov, K. Mukherjee, T.P. Moroz, Y. Bobkova, F. Yu, V.V. Kapitonov, J. Jurka, Y.V. Bobkov, J.J. Swore, D.O. Girardo, A. Fodor, F. Gusev, R. Sanford, R. Bruders, E. Kittler, C.E. Mills, J.P. Rast, R. Derelle, V.V. Solovyev, F.A. Kondrashov, B.J Swalla, J.V. Sweedler, E.I. Rogaev, K.M. Halanych, A.B. Kohn, The ctenophore genome and the evolutionary origins of neural systems, Nature 510 (2014) 109-114.

[63] M.J. Berridge, M.D. Bootman, H.L. Roderick, Calcium signalling: dynamics, homeostasis and remodelling, Nat. Rev. Mol. Cell Biol. 4 (2003) 517-529.

[64] H. Plattner, J. Hentschel, Sub-second cellular dynamics: time-resolved electron microscopy and functional correlation, Int. Rev. Cytol. 255 (2006) $133-176$.

[65] A. Haddad, A.P. Turkewitz, Analysis of exocytosis mutants indicates close coupling between regulated secretion and transcription activation in Tetrahymena, Proc. Natl. Acad. Sci. U. S. A. 94 (1997) 10675-10680.

[66] D.E. Clapham, Calcium signaling, Cell 131 (2007) 1047-1058.

[67] D.L. Prole, C.W. Taylor, Identification and analysis of putative homologues of mechanosensitive channels in pathogenic protozoa, PLOS ONE 8 (2013) e66068.

[68] B. Coste, J. Mathur, M. Schmidt, T.J. Earley, S. Ranade, M.J. Petrus, A.E. Dubin, A Patapoutian, Piezo1 and Piezo2 are essential components of distinct mechanically activated cation channels, Science 330 (2010) 55-60.

[69] M.K. Gould, H.P. de Koning, Cyclic-nucleotide signalling in protozoa, FEMS Microbiol. Rev. 35 (2011) 515-541.

[70] S.J. Fountain, K. Parkinson, M.T. Young, L. Cao, C.R. Thompson, R.A. North, An intracellular P2X receptor required for osmoregulation in Dictyostelium discoideum, Nature 448 (2007) 200-203.
[71] K. Parkinson, A.E. Baines, T. Keller, N. Gruenheit, L. Bragg, R.A. North, C.R. Thompson, Calcium-dependent regulation of Rab activation and vesicle fusion by an intracellular P2X ion channel, Nat. Cell Biol. 16 (2014) $87-98$.

[72] J. Choi, K. Tanaka, Y. Cao, Y. Qi, J. Qiu, Y. Liang, S.Y. Lee, G. Stacey, Identification of a plant receptor for extracellular ATP, Science 343 (2014) 290-294.

[73] F. Verret, G. Wheeler, A.R. Taylor, G. Farnham, C. Brownlee, Calcium channels in photosynthetic eukaryotes: implications for evolution of calcium-based signalling, New Phytol. 187 (2010) 23-43.

[74] Y. Pankratov, U. Lalo, O.A. Krishtal, A. Verkhratsky, P2X receptors and synaptic plasticity, Neuroscience 158 (2009) 137-148.

[75] J. Moniakis, M.B. Coukell, A. Forer, Molecular cloning of an intracellular P-type ATPase from Dictyostelium that is up-regulated in calcium-adapted cells, J. Biol. Chem. 270 (1995) 28276-28281.

[76] N.L. Elwess, J.L. Van Houten, Cloning and molecular analysis of the plasma membrane $\mathrm{Ca}^{2+}$-ATPase gene in Paramecium tetraurelia, J. Eukaryot. Microbiol. 44 (1997) 250-257.

[77] K. Hauser, N. Pavlovic, R. Kissmehl, H. Plattner, Molecular characterization of a sarco(endo)plasmic reticulum $\mathrm{Ca}^{2+}$-ATPase gene from Paramecium tetraurelia and localization of its gene product to sub-plasmalemmal calcium stores, Biochem. J. 334 (1998) 31-38.

[78] H. Tidow, L.R. Poulsen, A. Andreeva, M. Knudsen, K.L. Hein, C. Wiuf, M.G. Palmgren, P. Nissen, A bimodular mechanism of calcium control in eukaryotes, Nature 491 (2012) 468-472.

[79] M.C. Bonza, L. Luoni, Plant and animal type 2B $\mathrm{Ca}^{2+}$-ATPases: evidence for a common auto-inhibitory mechanism, FEBS Lett. 584 (2010) 4783-4788.

[80] W.A. Snedden, H. Fromm, Calmodulin, calmodulin-related proteins and plant responses to the environment, Trends Plant Sci. 3 (1998) 299-304.

[81] R. Docampo, G. Huang, Calcium signaling in trypanosomatid parasites, Cell Calcium 57 (2015) 194-202.

[82] S. Lourido, S.N.J. Moreno, The calcium signaling toolkit of the apicomplexan parasites Toxoplasma gondii and Plasmodium spp, Cell Calcium 57 (2015) 186-193.

[83] L. Almagor, M. Giladi, L. van Dijk, T. Buki, R. Hiller, D. Khananshvili, Functional asymmetry of bidirectional $\mathrm{Ca}^{2+}$-movements in an archaeal sodium-calcium exchanger (NCXMj), Cell Calcium 56 (2014) 276-284.

[84] H. Plattner, I.M. Sehring, I.K. Mohamed, K. Miranda, W. De Souza, R. Billington, A. Genazzani, E.M. Ladenburger, Calcium signaling in closely related protozoan groups (Alveolata): non-parasitic ciliates (Paramecium, Tetrahymena) vs. parasitic apicomplexa (Plasmodium, Toxoplasma), Cell Calcium 51 (2012) 351-382.

[85] I.M. Sehring, C. Klotz, J. Beisson, H. Plattner, Rapid downregulation of the $\mathrm{Ca}^{2+}$ signal after exocytosis stimulation in Paramecium cells: essential role of a centrin-rich filamentous cortical network, the infraciliary lattice, Cell Calcium 45 (2009) 89-97.

[86] H. Plattner, A. Habermann, R. Kissmehl, N. Klauke, I. Majoul, H.D. Söling, Differential distribution of calcium stores in Paramecium cells. Occurrence of a subplasmalemmal store with a calsequestrin-like protein, Eur. J. Cell Biol. 72 (1997) 297-306.

[87] H. Plattner, Molecular aspects of calcium signalling at the crossroads of unikont and bikont eukaryote evolution - the ciliated protozoan Paramecium in focus, Cell Calcium 57 (2015) 174-185

[88] J.H. Cho, Y.S. Oh, K.W. Park, J. Yu, K.Y. Choi, J.Y. Shin, D.H. Kim, W.J. Park, T. Hamada, H. Kagawa, E.B. Maryon, J. Bandyopadhyay, J. Ahnn, Calsequestrin, a calcium sequestering protein localized at the sarcoplasmic reticulum, is not essential for body-wall muscle function in Caenorhabditis elegans, J. Cell Sci. 113 (2000) 3947-3958.

[89] A. Müller-Taubenberger, A.N. Lupas, H. Li, M. Ecke, E. Simmeth, G. Gerisch, Calreticulin and calnexin in the endoplasmic reticulum are important for phagocytosis, EMBO J. 20 (2001) 6772-6782.

[90] D. Traynor, J.L. Milne, R.H. Insall, R.R. Kay, $\mathrm{Ca}^{2+}$ signalling is not required for chemotaxis in Dictyostelium, EMBO J. 19 (2000) 4846-4854

[91] X. Cai, Unicellular $\mathrm{Ca}^{2+}$ signaling 'toolkit' at the origin of metazoa, Mol. Biol. Evol. 25 (2008) 1357-1361.

[92] S. Fache, J. Dalous, M. Engelund, C. Hansen, F. Chamaraux, B. Fourcade, M. Satre, P. Devreotes, F. Bruckert, Calcium mobilization stimulates Dictyostelium discoideum shear-flow-induced cell motility, J. Cell Sci. 118 (2005) $3445-3457$

[93] E.M. Ladenburger, I. Korn, N. Kasielke, T. Wassmer, H. Plattner, An Ins (1,4,5)P receptor in Paramecium is associated with the osmoregulatory system, J. Cell Sci. 119 (2006) 3705-3717.

[94] E.M. Ladenburger, I.M. Sehring, I. Korn, H. Plattner, Novel types of $\mathrm{Ca}^{2+}$ release channels participate in the secretory cycle of Paramecium cells, Mol. Cell. Biol. 29 (2009) 3605-3622

[95] H. Plattner, Calcium signalling in the ciliated protozoan model, Paramecium: strict signal localisation by epigenetically controlled positioning of different $\mathrm{Ca}^{2+}$-channels, Cell Calcium 57 (2015) 123-132.

[96] O.A. Fedorenko, E. Popugaeva, M. Enomoto, P.B. Stathopulos, M. Ikura, Bezprozvanny, Intracellular calcium channels: inositol-1,4,5-trisphosphate receptors, Eur. J. Pharmacol. 739 (2014) 39-48.

[97] S. Fleischer, Personal recollections on the discovery of the ryanodine receptors of muscle, Biochem. Biophys. Res. Commun. 369 (2008) 195-207.

[98] H. Plattner, A. Verkhratsky, $\mathrm{Ca}^{2+}$ signalling early in evolution - all but primitive, J. Cell Sci. 126 (2013) 2141-2150. 
[99] N. Marchesini, F.A. Ruiz, M. Vieira, R. Docampo, Acidocalcisomes are functionally linked to the contractile vacuole of Dictyostelium discoideum, J. Biol. Chem. 277 (2002) 8146-8153.

[100] R. Docampo, W. de Souza, K. Miranda, P. Rohloff, S.N. Moreno, Acidocalcisomes - conserved from bacteria to man, Nat. Rev. Microbiol. 3 (2005) 251-261.

[101] H.C. Lee, Cyclic ADP-ribose and nicotinic acid adenine dinucleotide phosphate (NAADP) as messengers for calcium mobilization, J. Biol. Chem. 287 (2012) 31633-31640.

[102] D. Churamani, R. Hooper, T. Rahman, E. Brailoiu, S. Patel, The N-terminal region of two-pore channel 1 regulates trafficking and activation by NAADP, Biochem. J. 453 (2013) 147-151.

[103] A. Galione, A.M. Evans, J. Ma, J. Parrington, A. Arredouani, X. Cheng, M.X. Zhu, The acid test: the discovery of two-pore channels (TPCS) as NAADP-gated endolysosomal Ca ${ }^{2+}$ release channels, Pflugers Arch. 458 (2009) 869-876.

[104] S.J. Pitt, A.K. Lam, K. Rietdorf, A. Galione, R. Sitsapesan, Reconstituted human TPC1 is a proton-permeable ion channel and is activated by NAADP or $\mathrm{Ca}^{2+}$, Sci. Signal 7 (2014) ra46.

[105] H. Plattner, Contractile vacuole complex-its expanding protein inventory, Int. Rev. Cell. Mol. Biol. 306 (2013) 371-416.

[106] S. Patel, X. Cai, Evolution of acid $\mathrm{Ca}^{2+}$ stores and their resident $\mathrm{Ca}^{2+}$-permeable channels, Cell Calcium 57 (2015) 222-230.

[107] K.F. Swaney, C.H. Huang, P.N. Devreotes, Eukaryotic chemotaxis: a network of signaling pathways controls motility, directional sensing, and polarity, Annu. Rev. Biophys. 39 (2010) 265-289.

[108] W.C. Lima, A. Vinet, J. Pieters, P. Cosson, Role of PKD2 in rheotaxis in Dictyostelium, PLoS ONE 9 (2014) e88682.

[109] A. Baines, K. Parkinson, J.A. Sim, L. Bragg, C.R. Thompson, R.A. North, Functional properties of five Dictyostelium discoideum P2X receptors, J. Biol. Chem. 288 (2013) 20992-21000.

[110] V. Sivaramakrishnan, S.J. Fountain, Intracellular P2X receptors as novel calcium release channels and modulators of osmoregulation in Dictyostelium: a comparison of two common laboratory strains, Channels (Austin) 7 (2013) 43-46.

[111] S.R. Collins, T. Meyer, Evolutionary origins of STIM1 and STIM2 within ancient $\mathrm{Ca}^{2+}$ signaling systems, Trends Cell Biol. 21 (2011) 202-211.

[112] X.P. Dong, X. Wang, H. Xu, TRP channels of intracellular membranes, J. Neurochem. 113 (2010) 313-328.

[113] A. Hurtado-Lorenzo, M. Skinner, J. El Annan, M. Futai, G.H. Sun-Wada, S. Bourgoin, J. Casanova, A. Wildeman, S. Bechoua, D.A. Ausiello, D. Brown, V. Marshansky, V-ATPase interacts with ARNO and Arf6 in early endosomes and regulates the protein degradative pathway, Nat. Cell Biol. 8 (2006) 124-136.

[114] Y. Lin-Moshier, M.V. Keebler, R. Hooper, M.J. Boulware, X. Liu, D. Churamani, M.E. Abood, T.F. Walseth, E. Brailoiu, S. Patel, J.S. Marchant, The two-pore channel (TPC) interactome unmasks isoform-specific roles for TPCs in endolysosomal morphology and cell pigmentation, Proc. Natl. Acad. Sci. U. S. A. 111 (2014) 13087-13092.

[115] H. Plattner, Membrane trafficking in protozoa SNARE proteins, $\mathrm{H}^{+}$-ATPase, actin, and other key players in ciliates, Int. Rev. Cell Mol. Biol. 280 (2010) 79-184.

[116] W. Masuda, S. Takenaka, S. Tsuyama, M. Tokunaga, R. Yamaji, H. Inui, K. Miyatake, Y. Nakano, Inositol 1,4,5-trisphosphate and cyclic ADP-ribose mobilize $\mathrm{Ca}^{2+}$ in a protist, Euglena gracilis, Comp. Biochem. Physiol. C: Pharmacol. Toxicol. Endocrinol. 118 (1997) 279-283.

[117] G. Thiel, E.A. MacRobbie, D.E. Hanke, Raising the intracellular level of inositol 1,4,5-trisphosphate changes plasma membrane ion transport in characean algae, ЕMBO J. 9 (1990) 1737-1741.

[118] B. Klüsener, G. Boheim, H. Liss, J. Engelberth, E.W. Weiler, Gadoliniumsensitive, voltage-dependent calcium release channels in the endoplasmic reticulum of a higher plant mechanoreceptor organ, EMBO J. 14 (1995) $2708-2714$.

[119] S.R. Muir, D. Sanders, Inositol 1,4,5-trisphosphate-sensitive $\mathrm{Ca}^{2+}$ release across nonvacuolar membranes in cauliflower, Plant Physiol. 114 (1997) 1511-1521.

[120] Y. Kirichok, P.V. Lishko, Rediscovering sperm ion channels with the patchclamp technique, Mol. Hum. Reprod. 17 (2011) 478-499.

[121] A.B. Parekh, J.W. Putney Jr., Store-operated calcium channels, Physiol. Rev. 85 (2005) 757-810

[122] J.W. Putney Jr., Recent breakthroughs in the molecular mechanism of capacitative calcium entry (with thoughts on how we got here), Cell Calcium 42 (2007) 103-110.

[123] M.D. Cahalan, STIMulating store-operated Ca ${ }^{2+}$ entry, Nat. Cell Biol. 11 (2009) 669-677.

[124] R.S. Lewis, The molecular choreography of a store-operated calcium channel, Nature 446 (2007) 284-287.

[125] G.N. Huang, W.Zeng, J.Y. Kim, J.P. Yuan, L. Han, S. Muallem, P.F. Worley, STIM1 carboxyl-terminus activates native SOC, I $\mathrm{I}_{\mathrm{crac}}$ and TRPC1 channels, Nat. Cell Biol. 8 (2006) 1003-1010.

[126] J.P. Yuan, W. Zeng, G.N. Huang, P.F. Worley, S. Muallem, STIM1 heteromultimerizes TRPC channels to determine their function as store-operated channels, Nat. Cell Biol. 9 (2007) 636-645.

[127] G. Peng, X. Shi, T. Kadowaki, Evolution of TRP channels inferred by their classification in diverse animal species, Mol. Phylogenet. Evol. (2014), http://dx.doi.org/10.1016/j.ympev.2014.06.016.

[128] B. Nilius, G. Owsianik, The transient receptor potential family of ion channels, Genome Biol. 12 (2011) 218.
[129] H. Plattner, N. Klauke, Calcium in ciliated protozoa: sources, regulation, and calcium-regulated cell functions, Int. Rev. Cytol. 201 (2001) 115-208.

[130] F. Giordano, Y. Saheki, O. Idevall-Hagren, S.F. Colombo, M. Pirruccello, I. Milosevic, E.O. Gracheva, S.N. Bagriantsev, N. Borgese, P. De Camilli, PI(4,5) $\mathrm{P}_{2}$ dependent and $\mathrm{Ca}^{2+}$-regulated ER-PM interactions mediated by the extended synaptotagmins, Cell 153 (2013) 1494-1509.

[131] G. Lavieu, L. Orci, L. Shi, M. Geiling, M. Ravazzola, F. Wieland, P. Cosson, J.E. Rothman, Induction of cortical endoplasmic reticulum by dimerization of a coatomer-binding peptide anchored to endoplasmic reticulum membranes, Proc. Natl. Acad. Sci. U. S. A. 107 (2010) 6876-6881.

[132] W.A. Prinz, Bridging the gap: membrane contact sites in signaling, metabolism, and organelle dynamics, J. Cell Biol. 205 (2014) 759-769.

[133] C.J. Stefan, A.G. Manford, D. Baird, J. Yamada-Hanff, Y. Mao, S.D. Emr, Osh proteins regulate phosphoinositide metabolism at ER-plasma membrane contact sites, Cell 144 (2011) 389-401.

[134] D. Malchow, D.F. Lusche, A. De Lozanne, C. Schlatterer, A fast $\mathrm{Ca}^{2+}$-induced $\mathrm{Ca}^{2+}$-release mechanism in Dictyostelium discoideum, Cell Calcium 43 (2008) 521-530.

[135] F. Friedberg, A.R. Rhoads, Evolutionary aspects of calmodulin, IUBMB Life 51 (2001) 215-221.

[136] I. Ivanovska, M.D. Rose, Fine structure analysis of the yeast centrin, Cdc31p, identifies residues specific for cell morphology and spindle pole body duplication, Genetics 157 (2001) 503-518.

[137] L. Madeddu, C. Klotz, J.P. Le Caer, J. Beisson, Characterization of centrin genes in Paramecium, Eur. J. Biochem. 238 (1996) 121-128.

[138] J. Molinier, C. Ramos, O. Fritsch, B. Hohn, CENTRIN2 modulates homologous recombination and nucleotide excision repair in Arabidopsis, Plant Cell 16 (2004) 1633-1643.

[139] (a) I. Zamora, W.F. Marshall, A mutation in the centriole-associated protein centrin causes genomic instability via increased chromosome loss in Chlamydomonas reinhardtii, BMC Biol. 3 (2005) 15;

(b) M. Craxton, Synaptotagmin gene content in the sequenced genomes, BMC Genom. 5 (2004) 43.

[140] J. Rizo, X. Chen, D. Arac, Unraveling the mechanisms of synaptotagmin and SNARE function in neurotransmitter release, Trends Cell Biol. 16 (2006) 339-350.

[141] T.C. Südhof, Neurotransmitter release: the last millisecond in the life of a synaptic vesicle, Neuron 80 (2013) 675-690.

[142] C. Li, B. Ullrich, J.Z.Zhang, R.G. Anderson, N. Brose, T.C. Südhof, $\mathrm{Ca}^{2+}$-dependent and-independent activities of neural and non-neural synaptotagmins, Nature 375 (1995) 594-599.

[143] S.W. Min, W.P. Chang, T.C. Südhof, E-Syts, a family of membranous Ca ${ }^{2+}$-sensor proteins with multiple C2 domains, Proc. Natl. Acad. Sci. U. S. A. 104 (2007) 3823-3828.

[144] Z.P. Pang, T.C. Südhof, Cell biology of $\mathrm{Ca}^{2+}$-triggered exocytosis, Curr. Opin. Cell Biol. 22 (2010) 496-505.

[145] L. Eichinger, J.A. Pachebat, G. Glockner M.A. Rajandream, R. Sucgang M. Berriman, J. Song, R. Olsen, K. Szafranski, Q. Xu, B. Tunggal, S. Kummerfeld, M. Madera, B.A. Konfortov, F. Rivero, A.T. Bankier, R. Lehmann, N. Hamlin, R. Davies, P. Gaudet, P. Fey, K. Pilcher, G. Chen, D. Saunders, E. Sodergren, P. Davis, A. Kerhornou, X. Nie, N. Hall, C. Anjard, L. Hemphill, N. Bason, P. Farbrother B. Desany, E Just T. Morio, R. Rost C. Churcher, J Cooper, S. Haydock, N. van Driessche, A. Cronin, I. Goodhead, D. Muzny, T. Mourier, A. Pain, M. Lu, D. Harper, R. Lindsay, H. Hauser, K. James, M. Quiles, M. Madan Babu, T. Saito, C. Buchrieser, A. Wardroper, M. Felder, M. Thangavelu, D. Johnson, A. Knights, H. Loulseged, K. Mungall, K. Oliver, C. Price, M.A. Quail, H. Urushihara, J. Hernandez, E. Rabbinowitsch, D. Steffen, M. Sanders, J. Ma, Y. Kohara, S. Sharp, M. Simmonds, S. Spiegler, A. Tivey, S. Sugano, B. White, D. Walker, J. Woodward, T. Winckler, Y. Tanaka, G. Shaulsky, M. Schleicher, G. Weinstock, A. Rosenthal, E.C. Cox, R.L. Chisholm, R. Gibbs, W.F. Loomis, M. Platzer, R.R. Kay, J. Williams, P.H. Dear, A.A. Noegel, B. Barrell, A. Kuspa, The genome of the social amoeba Dictyostelium discoideum, Nature 435 (2005) 43-57.

[146] H. Kasai, Comparative biology of $\mathrm{Ca}^{2+}$-dependent exocytosis: implications of kinetic diversity for secretory function, Trends Neurosci. 22 (1999) 88-93.

[147] V. Parpura, R. Zorec, Gliotransmission: exocytotic release from astrocytes, Brain Res. Rev. 63 (2010) 83-92.

[148] D. Kerboeuf, A. Le Berre, J.C. Dedieu, J. Cohen, Calmodulin is essential for assembling links necessary for exocytotic membrane fusion in Paramecium, EMBO J. 12 (1993) 3385-3390.

[149] S. Quetglas, C. Iborra, N. Sasakawa, L. De Haro, K. Kumakura, K. Sato, C. Leveque, M. Seagar, Calmodulin and lipid binding to synaptobrevin regulates calciumdependent exocytosis, EMBO J. 21 (2002) 3970-3979

[150] D. Wang, D. Epstein, O. Khalaf, S. Srinivasan, W.R. Williamson, A. Fayyazuddin, F.A. Quiocho, P.R. Hiesinger, $\mathrm{Ca}^{2+}$-calmodulin regulates SNARE assembly and spontaneous neurotransmitter release via v-ATPase subunit V0a1, J. Cell Biol. 205 (2014) 21-31.

[151] C.E. Creutz, J.L. Tomsig, S.L. Snyder, M.C. Gautier, F. Skouri, J. Beisson, J. Cohen, The copines, a novel class of C2 domain-containing, calcium-dependent, phospholipid-binding proteins conserved from Paramecium to humans, J. Biol. Chem. 273 (1998) 1393-1402.

[152] C.K. Damer, M. Bayeva, E.S. Hahn, J. Rivera, C.I. Socec, Copine A, a calciumdependent membrane-binding protein, transiently localizes to the plasma membrane and intracellular vacuoles in Dictyostelium, BMC Cell Biol. 6 (2005) 46.

[153] J.L. Tomsig, C.E. Creutz, Copines: a ubiquitous family of $\mathrm{Ca}^{2+}$-dependent phospholipid-binding proteins, Cell. Mol. Life Sci. 59 (2002) 1467-1477. 
[154] T. Nakayama, T. Yaoi, G. Kuwajima, Localization and subcellular distribution of N-copine in mouse brain, J. Neurochem. 72 (1999) 373-379.

[155] V. Gerke, C.E. Creutz, S.E. Moss, Annexins: linking $\mathrm{Ca}^{2+}$ signalling to membrane dynamics, Nat. Rev. Mol. Cell Biol. 6 (2005) 449-461.

[156] J.M. Goldberg, G. Manning, A. Liu, P. Fey, K.E. Pilcher, Y. Xu, J.L. Smith, The Dictyostelium kinome - analysis of the protein kinases from a simple model organism, PLoS Genet. 2 (2006) e38.

[157] K. Kim, L.A. Messinger, D.L. Nelson, $\mathrm{Ca}^{2+}$-dependent protein kinases of Paramecium - cloning provides evidence of a multigene family, Eur. J. Biochem. 251 (1998) 605-612.

[158] L. Aravind, L.M. Iyer, T.E. Wellems, L.H. Miller, Plasmodium biology: genomic gleanings, Cell 115 (2003) 771-785

[159] S. Luan, W. Lan, S. Chul Lee, Potassium nutrition, sodium toxicity, and calcium signaling: connections through the CBL-CIPK network, Curr. Opin. Plant Biol. 12 (2009) 339-346

[160] G.R. Valmonte, K. Arthur, C.M. Higgins, R.M. MacDiarmid, Calcium-dependent protein kinases in plants: evolution, expression and function, Plant Cell Physiol. 55 (2014) 551-569.

[161] Y. Liang, J. Pan, Regulation of flagellar biogenesis by a calcium dependent protein kinase in Chlamydomonas reinhardtii, PLoS ONE 8 (2013) e69902.

[162] A. Goldman, J. Roy, B. Bodenmiller, S. Wanka, C.R. Landry, R. Aebersold M.S. Cyert, The calcineurin signaling network evolves via conserved kinasephosphatase modules that transcend substrate identity, Mol. Cell 55 (2014) 422-435.

[163] F. Rusnak, P. Mertz, Calcineurin: form and function, Physiol. Rev. 80 (2000) $1483-1521$

[164] H. Dammann, S. Hellstern, O. Husain, R. Mutzel, Primary structure, expression and developmental regulation of a Dictyostelium calcineurin A homologue, Eur. J. Biochem. 238 (1996) 391-399.

[165] D. Fraga, I.M. Sehring, R. Kissmehl, M. Reiss, R. Gaines, R. Hinrichsen, H. Plattner, Protein phosphatase 2B (PP2B, calcineurin) in Paramecium: partial characterization reveals that two members of the unusually large catalytic subunit family have distinct roles in calcium-dependent processes, Eukaryot. Cell 9 (2010) 1049-1063.

[166] S. Thewes, Calcineurin-Crz1 signaling in lower eukaryotes, Eukaryot. Cell 13 (2014) 694-705.

[167] E. Giurisato, A. Gamberucci, C. Ulivieri, S. Marruganti, E. Rossi, E. Giacomello, D. Randazzo, V. Sorrentino, The KSR2-calcineurin complex regulates STIM1ORAI1 dynamics and store-operated calcium entry (SOCE), Mol. Biol. Cell 25 (2014) 1769-1781.

[168] P. Burkhardt, M. GrØnborg, K. McDonald, T. Sulur, Q. Wang, N. King, Evolutionary insights into premetazoan functions of the neuronal protein homer, Mol. Biol. Evol. 31 (2014) 2342-2355.
[169] C.M. Klinger, R.E. Nisbet, D.T. Ouologuem, D.S. Roos, J.B. Dacks, Cryptic organelle homology in apicomplexan parasites: insights from evolutionary cell biology, Curr. Opin. Microbiol. 16 (2013) 424-431.

[170] E. Alves, P.J. Bartlett, C.R. Garcia, A.P. Thomas, Melatonin and $\mathrm{IP}_{3}$-induced $\mathrm{Ca}^{2+}$ release from intracellular stores in the malaria parasite Plasmodium falciparum within infected red blood cells, J. Biol. Chem. 286 (2011) 5905-5912.

[171] J.L. Lovett, N. Marchesini, S.N. Moreno, L.D. Sibley, Toxoplasma gondii microneme secretion involves intracellular $\mathrm{Ca}^{2+}$ release from inositol 1,4,5triphosphate $\mathrm{IP}_{3} /$ ryanodine-sensitive stores, J. Biol. Chem. 277 (2002) 25870-25876.

[172] A.P. Passos, C.R. Garcia, Inositol 1,4,5-trisphosphate induced $\mathrm{Ca}^{2+}$ release from chloroquine-sensitive and -insensitive intracellular stores in the intraerythrocytic stage of the malaria parasite P. chabaudi, Biochem. Biophys. Res. Commun. 245 (1998) 155-160.

[173] P. Sharma, C.E. Chitnis, Key molecular events during host cell invasion by Apicomplexan pathogens, Curr. Opin. Microbiol. 16 (2013) 432-437.

[174] G. Huang, P.J. Bartlett, A.P. Thomas, S.N. Moreno, R. Docampo, Acidocalcisomes of Trypanosoma brucei have an inositol 1,4,5-trisphosphate receptor that is required for growth and infectivity, Proc. Natl. Acad. Sci. U. S. A. 110 (2013) 1887-1892.

[175] M. Hashimoto, M. Enomoto, J. Morales, N. Kurebayashi, T. Sakurai, T. Hashimoto, T. Nara, K. Mikoshiba, Inositol 1,4,5-trisphosphate receptor regulates replication, differentiation, infectivity and virulence of the parasitic protist Trypanosoma cruzi, Mol. Microbiol. 87 (2013) 1133-1150.

[176] O. Batistic, J. Kudla, Plant calcineurin B-like proteins and their interacting protein kinases, Biochim. Biophys. Acta 1793 (2009) 985-992.

[177] J.F. Harper, G. Breton, A. Harmon, Decoding $\mathrm{Ca}^{2+}$ signals through plant protein kinases, Annu. Rev. Plant Biol. 55 (2004) 263-288.

[178] S. Luan, J. Kudla, M. Rodriguez-Concepcion, S. Yalovsky, W. Gruissem, Calmodulins and calcineurin B-like proteins: calcium sensors for specific signal response coupling in plants, Plant Cell 14 (Suppl.) (2002) S389-S400.

[179] W.I. Weis, W.J. Nelson, D.J. Dickinson, Evolution and cell physiology. 3. Using Dictyostelium discoideum to investigate mechanisms of epithelial polarity, Am. J. Physiol. Cell Physiol. 305 (2013) C1091-C1095.

[180] E.S. Cole, D. Cassidy-Hanley, J. Fricke Pinello, H. Zeng, M. Hsueh, D. Kolbin, C. Ozzello, T. Giddings Jr., M. Winey, T.G. Clark, Function of the male-gametespecific fusion protein HAP2 in a seven-sexed ciliate, Curr. Biol. 24 (2014) 2168-2173.

[181] M. Abedin, N. King, The premetazoan ancestry of cadherins, Science 319 (2008) 946-948.

[182] K. Baumgärtel, I.M. Mansuy, Neural functions of calcineurin in synaptic plasticity and memory, Learn. Mem. 19 (2012) 375-384

[183] G. Schönknecht, A.P. Weber, M.J. Lercher, Horizontal gene acquisitions by eukaryotes as drivers of adaptive evolution, Bioessays 36 (2014) 9-20. 